\title{
DRINKING WATER QUALITY - A HEALTH PERSPECTIVE
}

John W Archer

Author, On The Water Front (1991)

O ne major problem confronting scientists interested in possible links between health and drinking water has always been the difficulty of proof. It is not easy to demonstrate whether a connection exists between common disorders like gastroenteritis and water supplies. A Victorian Department of Water Resources report points out that many Australian epidemics of waterborne diseases such as hepatitis, gastroenteritis and amoebic dysentery have not been documented or recorded because they "were not scientifically proven to be linked to drinking water".

The report continues: "... to prove an association of drinking or bathing or washing food in contaminated water with sickness requires an expensive and comprehensive investigation which can therefore rarely be carried out".

This problem is not new. Although many believed there might be some connection, it was not until late in the 19 th century that microscope studies began to reveal the existence of deadly bacteria in some water supplies. However, authorities did not see any cause for alarm. London water engineer Ralph Dodd wrote in 1805: "Thames water being kept in wooden vessels, after a few months, often becomes putrid ... and produces a disagreeable smell. But even when drunk in this state, it never produces sickness; therefore it is evident no harm or ill occurs to persons whose resolution, notwithstanding its offensive smell, induces them to drink it."

Thirty years later thousands of Londoners died in the first of several cholera epidemics which recurred until the $1860 \mathrm{~s}$ when people began to connect the disease with drinking water. Even so, given the existing levels of pollution, it did not appear much could be done to make it safe.

In $1904 \mathrm{Sir}$ Alexander Houston discovered that the addition of chlorine to water could destroy the typhoid bacillus. Excited scientists soon found that disinfecting water with chlorine also eliminated cholera, dysentery and several other waterborne diseases which often resulted in epidemics. Most water treatment systems since then have been designed to disinfect water with chlorine to achieve an acceptable level of bacteriological safety.

To check whether the disinfection process was working properly water scientists and microbiologists evolved a series of tests using organisms known as coliforms. Coliforms and Escherichia coli (E. coli) are part of a group of largely benign bacteria whose presence in water may be an indication that the water may be contaminated. They are the normal inhabitants of the gut of birds, humans and other warm-blooded animals, and are not capable of surviving in water for long periods. Coliforms are used as indicators because if they are detected in water, their presence indicates that excrement has polluted the water, and that other more serious pathogens may also be present.

E. coli is a member of the coliform group which is predominant in fresh faeces, so its presence in water indicates recent faecal contamination. Both coliforms and $\mathrm{E}$. coli are counted by water laboratories as part of regular tests to ascertain the microbiological quality of water supplies. It is on the basis of these examinations that our water is pronounced safe. However bacteria may not be the only threat.

A major Canadian study recently revealed an association between gastrointestinal symptoms and tap water consumption, and casts serious doubts about the methods used to evaluate drinking water quality. The study, commissioned by the University of Quebec, was conducted on 600 families. Half those surveyed drank water which had been treated by the City of Montreal's modern treatment plant while the balance consumed the same water after further home treatment with a reverse osmosis purifier.

The drinking water met all the standards required to assure its bacteriological safety as well as all the other normally accepted water quality guidelines. It was pronounced to be "perfectly safe and of high quality". The same words are frequently used to describe Australian tap water supplies. It is important to note that this water supply was prepared from sewage-contaminated surface waters.

The Canadian study demonstrates that, in spite of meeting these standards, the water was "found to be associated with a significant level of gastrointestinal illnesses". The group who purified their tap water at home had 30 per cent fewer gastrointestinal disorders during the 18-month study.

The authors warn that water treatment systems based on disinfection for bacteria are ineffective against many parasites and viruses and consequently the use of coliforms to indicate water quality may result in "a false sense of security".

The presence of Cryptosporidium parvum is causing particular concern to water authorities in Australia and the USA. For example, it is now estimated that 380,000 people were affected by the epidemic of cryptosporidiosis which occurred in Milwaukee, Wisconsin, in April 1993. City officials believe the parasite, which is not killed by chlorination, may have contaminated the municipal water supply after passing through the existing treatment plant.

In July 1993 in Sydney there was considerable public interest when the media discovered an environmental impact study which revealed that Cryptosporidium had been found in all the Sydney Water Board's storages and at several locations in the pipeline system "at levels similar to those found in the UK and the USA".

The water was pronounced safe to drink because the number of parasites found was "extremely low". However the World Health Organisation and other authorities believe there is not yet enough information about what constitutes an infective dose. As one British scientist points out: "This is a crucial issue for the water industry. Currently nationally recommended methods do not provide an indication of the infective potential of oocysts. Presently the prudent assumption is made that any oocyst is capable of causing infection. ${ }^{n 4}$

A month later the problem re-emerged when 10 districts around Melbourne were warned to boil their water because of the levels of Cryptosporidium in the Tarago reservoir.

With new Australian technology recently developed for the detection of viruses and parasites in water, it appears there's a lot more to be learned about the connection between water and community health.

One problem with suggesting routine analysis for Cryptosporidium and giardia is that they are expensive and very time-consuming. The National Health and Medical Research Council does not recommend routine analysis for Cryptosporidium or giardia.

1. Dept Water Resources, Vic. Microbiological Drinking Water Quality, 1985 p5.

2. Weightman, Gavin. London River 1990 p129.

3. Payment, P, Franco, E, Siemiatycki, J. Absence of relationship between health effects due to tap water consumption and drinking water quality parameters. Wat Sci Tech 1993. Vol 27 No 3-4, pp 137-143. 4. Benton, C, Ives, KJ, Miller, DG, West, PA. Cryptosporidum in Water. 1991 p6. 


\section{EDITORIAL COMMENTS}

The Health Department, with other health authorities and water supply agencies, has recognised the potential importance of protozoan parasites in drinking water supplies and their possible role in previously unexplained outbreaks of gastroenteritis.

Mr Archer raises the issue whether Cryptosporidium should be monitored routinely. The key issue, however, is the role of indicators and the way this information is used in managing water supplies. Knowledge of the environmental conditions in the drinking water catchments is critical. The Department strongly supports the principle of multiple barriers based first on raw water of the highest possible quality. Indicators then are used for quality control and, where necessary, additional indicators can be used to test for probable contamination based on knowledge of the catchments. It is not necessary to test for all the individual contaminants of concern.

The Canadian water supply referred to by $\mathrm{Mr}$ Archer was known to be contaminated with human sewage. This raises a number of questions:

- Were the treatment processes provided appropriate given this source of contamination?

Did the indicators used provide assurance of process control and, therefore, water quality?

What were the environmental and recreational impacts to the waterways and the consequences for all users of the water?

These questions need a broad, strategic answer and cannot be avoided by a different monitoring regime. In assessing the implications of the new water plants the Water Board has made such a holistic commitment to managing Sydney's water supply. As well as upgrading the water treatment processes, the Water Board has a concurrence role over development in the "inner catchments"; it is promoting catchment management of privately owned land and is eliminating or upgrading sewage effluent disposal within the catchments.

Based on information provided by the Water Board the Department does not believe the levels of Cryptosporidium found in Sydney's water supply in June 1993 represented a public health threat. Mr Archer is quite right, however, when he states that we really do not know the infective dose for Cryptosporidium. It is considered to be quite low maybe 10 oocysts or fewer, and possibly as low as 1 oocyst per person. Certainly the dose will vary for individuals and is most critical for immunologically impaired groups. The absence of a specific action level for Cryptosporidium in the most recent (draft) NHMRC Guidelines for Drinking Water is a reflection of this uncertainty. An animal model has recently been developed which may provide more information on the behaviour of the organism.

The Health Department is developing a more clearly defined audit role for drinking water quality as a result of the proposed corporatisation of the Water Board. Any agreement will address all issues of water quality, including raw water supplies, quality assurance/quality control and the most appropriate indicators for routine and event monitoring.

\section{PUBlic HEALTH ABSTRACTS} School of Health Service Management at the University of NSW, has prepared the following public health items from the literature.

\section{HIGH RATES OF DISABILITY IN IMMATURE INFANTS}

Neo-natal intensive care has been described as 'perhaps the most successful of all medical technologies'. In terms of improving the chance of survival this may be so, but the rate of disabilities among the survivors is high as has been shown by a comprehensive survey involving nearly 100,000 infants in the United Kingdom. About 3.5 of 1,000 of these births were before 29 weeks of gestation. Half the babies survived to be discharged from the nursery. At four years, 93 per cent of the premature infants were still alive. Only 35 per cent of those four-year-olds were within normal limits. Around 29 per cent had mild disability, 13 per cent a moderate disability and 23 per cent were severely disabled. The severe disablements included cerebral palsy, blindness, severe hearing loss and intellectual handicap. A number of babies had multiple disabilities. An important finding was that the incidence of disability increases with declining gestational age of the babies.

Johnson A, Townshend P, Yudkin $P$ et al. Functional abilities at age 4 years of children born before 29 weeks of gestation. $\mathrm{Br}$ Med J, 1993; 306:1715-1718.

\section{NEVER DISMISS WHAT A PATIENT TELLS YOU}

When a 90-year-old was admitted to hospital he asked the staff to let his mother know. The doctors thought he must be senile. In fact, his mother, at 113 years, is the oldest woman in Britain.

\section{Editorial. Br Med J, 1993; 307:48-49.}

\section{SEX, PREGNANCY, HORMONES AND MELANOMA}

Many questions remain unanswered about the relationship between melanoma (the most rapidly increasing Australian cancer) and the hormonal environment. Several conclusions can be made within the current state of knowledge. First, there is no evidence that the use of oestrogens, either as oral contraceptives or hormone replacement therapy, has a role in the aetiology of melanoma. Second, women have a survival advantage over men that could be due to the inhibitory effect of normal oestrogens in the growth of melanoma. Third, prescribed oestrogens do not promote progression of the disease in patients with melanoma, therefore women who have been treated for melanoma can safely use hormonal supplements. Last, pregnancy seems to carry no adverse effect on survival after treatment for melanoma. (However, patients with thick melanomic lesions are advised to delay pregnancy for two to three years as this is when they are at the greatest risk of relapse).

Jatoi I and Gore ME. Sex, pregnancy, hormones and melanoma. $\mathrm{Br} \mathrm{Med}$ $J, 1993 ; 307: 2-3$.

\section{BREAST-FEEDING REDUCES RISK OF BREAST CANCER}

A large British study has confirmed that breast-feeding is associated with a statistically significant decreased risk of breast cancer. The risk of breast cancer falls with increased duration of breast-feeding, and with the number of babies breast-fed. However, breast-feeding each baby for longer than three months confers no additional benefits.

United Kingdom National Case-Control Study Group. Breast feeding and risk of breast cancer in young women. $B r$ Med $J, 1993 ; 307: 17-20$. 